\title{
Chemical, Antioxidant, and Antimicrobial Evaluation of Essential Oils and an Anatomical Study of the Aerial Parts from Baccharis Species (Asteraceae)
}

\author{
Tatiana Zuccolotto, ${ }^{a}$ Jaqueline Bressan, ${ }^{a}$ Allan V. F. Lourenço, ${ }^{a}$ Estevan Bruginski, ${ }^{a}$ Andressa Veiga, \\ Jane V. N. Marinho, ${ }^{\mathrm{b}}$ Paola A. Raeski, ${ }^{\mathrm{c}}$ Gustavo Heiden, ${ }^{\mathrm{d}}$ Marcos J. Salvador, ${ }^{\mathrm{b}}$ Fabio S. Murakami, ${ }^{\mathrm{a}}$ \\ Jane M. Budel, ${ }^{\mathrm{C}}$ and Francinete R. Campos*a \\ a Departamento de Farmácia, Universidade Federal do Paraná (UFPR), Av. Pref. Lothário Meissner, 632, Jardim \\ Botânico, 80210-170 Curitiba, PR, Brasil, e-mail: francampos@ufpr.br \\ ${ }^{b}$ Departamento de Biologia Vegetal, Instituto de Biologia, Universidade Estadual de Campinas (Unicamp), Barão \\ Geraldo, 13083-971 Campinas, SP, Brasil \\ ' Departamento de Ciências Farmacêuticas, Universidade Estadual de Ponta Grossa (UEPG), Av. General Carlos \\ Cavalcanti, 4.748, Uvaranas, 84030-900 Ponta Grossa, PR, Brasil \\ d Embrapa Clima Temperado, BR 392, Km 789, 96010-971 Pelotas, RS, Brasil
}

The aim of this study was to evaluate the chemical, antioxidant, and antimicrobial activity of the essential oils as well as the anatomy of the aerial parts from Baccharis aracatubaensis, Baccharis burchellii, and Baccharis organensis owing to the therapeutic potential of Baccharis. The volatile constituents were analyzed using GC/MS, the antioxidant activity was evaluated by oxygen radical absorbance capacity (ORAC $\mathrm{FL}_{\mathrm{L}}$ ) and $\mathrm{DPPH}$ assays, and the antimicrobial activity by a microdilution technique. Of the 56 compounds identified, only seven ( $\beta$-caryophyllene, $\gamma$-muurolene, bicyclogermacrene, $\beta$-germacrene, spathulenol, $\tau$-muurolol, and $\alpha$-cadinol) were common in the three specimens studied. Of these, $\gamma$-muurolene was found abundantly in $B$. aracatubaensis, while bicyclogermacrene was abundant in $B$. burchellii and $B$. organensis. The essential oils exhibited antioxidant activity in the $\mathrm{ORAC}_{\mathrm{FL}}\left(>500.0 \mu \mathrm{molTEg}^{-1}\right)$ and DPPH assays. However, they did not exhibit any antimicrobial activity. Secretory ducts and flagelliform glandular trichomes were observed in the anatomical study of all the Baccharis species studied.

Keywords: Baccharis, essential oils, terpenoids, anatomical study, antimicrobial activity, antioxidant activity, biological activity.

\section{Introduction}

Asteraceae is among the largest species-rich families within the angiosperms, comprising of approximately 23,000 species belonging to 1,600 genera. ${ }^{[1]}$ Between these genera stands out Baccharis L., which is one of the 10 most diverse genera of the family, with approximately 400 species distributed from Canada to Southern Argentina and Chile. ${ }^{[2]}$ In Brazil, there are 178 species currently present across all biomes and are found to be more abundant in the South, Southeast and Midwest regions. ${ }^{[3]}$ Among these, Baccharis aracatubaensis MALAG. is included in the vulnerable and almost endangered Red list under the classification, ${ }^{[3]}$ justifying the importance of studies with this species. B. aracatubaensis popularly known as broom is a subshrub native to Brazil that belongs to the Axillaris section, growing approximately up to $1.2 \mathrm{~m}$ high, and restricted to the states of Santa Catarina and Paraná. ${ }^{4]}$ Baccharis burchellii BAKER, popularly known as 'alecrimcarqueja' belongs to the Caulopterae section. It is exclusively distributed in Brazil, being endemic to the Southeastern Region (Minas Gerais, Rio de Janeiro, and São Paulo), and occurring in the Atlantic Forest Biome. ${ }^{[5]}$ Baccharis organensis BAKER, which belongs to the Caulopterae section, is popularly known as broom, 
and is a branched shrub native to Brazil that grows approximately $1.0 \mathrm{~h}$ high, and is geographically distributed in Rio de Janeiro ('Serra dos órgãos' and 'Itatiaia'), Paraná, Santa Catarina, and Rio Grande do Sul. ${ }^{[4,5]}$

Asteraceae is considered to be one among approximately 50 families of plants that produce essential oils. In this family, oils are found in the anatomical structures. In Baccharis, secretory ducts are generally observed. Due to the great difficulty that arises while identifying plants from Baccharis species, several studies have been performed using these secretory structures to distinguish these species, especially the 'carquejas'. Many studies have examined its morphoanatomical characteristics to determine the pharmacobotanical characters of the taxon and support the quality control of vegetable drugs. ${ }^{[6-9]}$

According to a review realized in 2016 by Campos and collaborators, ${ }^{[10]}$ the plants of the genus Baccharis are rich in volatile organic compounds. However, approximately 50 species had the chemical composition of the essential oils studied. There have been few studies on chemical characterization, according to male and female specimens separately. ${ }^{[1-13]}$

Several pharmacological activities are attributed to essential oils, including antioxidant, antimicrobial, antiinflammatory, antifungal, acetylcholinesterase, antiprotozoal, analgesic, antiparasitic, sedative, insecticidal, antitrypanosomal, and antitumor. ${ }^{[10,14-19]}$ In addition, these oils are widely used as fragrance in cosmetics and cleaning products, as well as use in food and medicine as additives, because of their antioxidant, antimicrobial, and flavoring properties. ${ }^{[20-29]}$

Among Baccharis species, the most studied species of high socio-economic value is Baccharis dracunculifolia DC., which is known to be the main plant source of Brazilian green propolis. It is widely used for its antimicrobial, anti-inflammatory, and analgesic effects. ${ }^{[30,31]}$ This species also produces $(E)$-nerolidol, a high value compound for the perfume industry. ${ }^{[32]}$ Baccharis salicifolia (RUIZ \& PAV.) PERS. and Baccharis pilularis DC. produce a nectar that leads to the production of high quality honey. ${ }^{[33]}$ Baccharis trimera (LESS.) DC. is widely used in folk medicine as a digestive aid, diuretic, hepatoprotective, anti-inflammatory, and antihypertensive agent, as well as in detoxification and control of obesity, ${ }^{[34-36]}$ and also produce carquejil acetate of high value for the perfume industry. ${ }^{[32]}$

Due to the ethnobotanical and pharmacological importance of Baccharis and the concomitant depletion of species in the Brazilian biomes, study of Baccharis species holds great importance. Therefore, the aim of this study was to evaluate the chemical, antioxidant, and antimicrobial activity of essential oils obtained from the flowers of male and female specimens and the study of the anatomy of secretory structures of the aerial vegetative organs of $B$. aracatubaensis, B. burchellii, and B. organensis.

\section{Results and Discussion}

The inflorescence of the male and female specimens of $B$. aracatubaensis, B. burchellii, and $B$. organensis yielded a light yellow crude essential oil. The yield in relation to the dry weight of the plant material for male and female specimens were $0.17 \%$ and $0.14 \%$ for $B$. aracatubaensis, $0.10 \%$ for both the specimens of $B$. burchellii and B. organensis, respectively.

As shown in Table 1, 56 compounds were identified in the chemical composition of the essential oils from the three Baccharis species studied. The essential oils of these species revealed a high proportion of sesquiterpenes in male and female specimens of $B$. aracatubaensis $(89.2 \%$ and $100 \%$, respectively), $B$. burchellii (100\% for both the specimens), and $B$. organensis ( $99.0 \%$ and $91.2 \%$, respectively). The monoterpenes were observed in small amounts in all the analyzed specimens, while $\alpha$-thujene, sabinene, and limonene were observed only in the male specimens of $B$. aracatubaensis $(10.3 \%)$ and in the female specimens of $B$. organensis (6.8\%). However, in the male specimens of $B$. organensis, only $\alpha$-thujene and sabinene were observed (0.9\%). Monoterpenes were not found in $B$. burchellii. Of the 56 compounds identified, only seven compounds $((\beta)$-caryophyllene, $\gamma$-muurolene, bicyclogermacrene, $\beta$-germacrene, spathulenol, $\tau$-muurolol, and $\alpha$-cadinol) were common in all the specimens analyzed.

According to the results obtained by HCA analysis (Figure 1), similarities were observed among the male and female specimens of the Baccharis species studied. There are only a few studies comparing male and female specimens despite a large population of dioecious species in Baccharis. These studies show that there may or may not be differences in the chemical composition of the essential oils of male and female Baccharis specimens. ${ }^{[11-13,39-42]}$ However, with HCA analysis (Figure 1), it was possible to observe a great similarity in the composition between the essential oils from $B$. aracatubaensis and $B$. organensis, which are the representatives of different sections, Axillaris and Caulopterae, respectively. This similarity can be explained by the stage of plant development and 
Table 1. Essential oil composition of male and female specimens from Baccharis aracatubaensis, B. burchellii, and B. organensis.

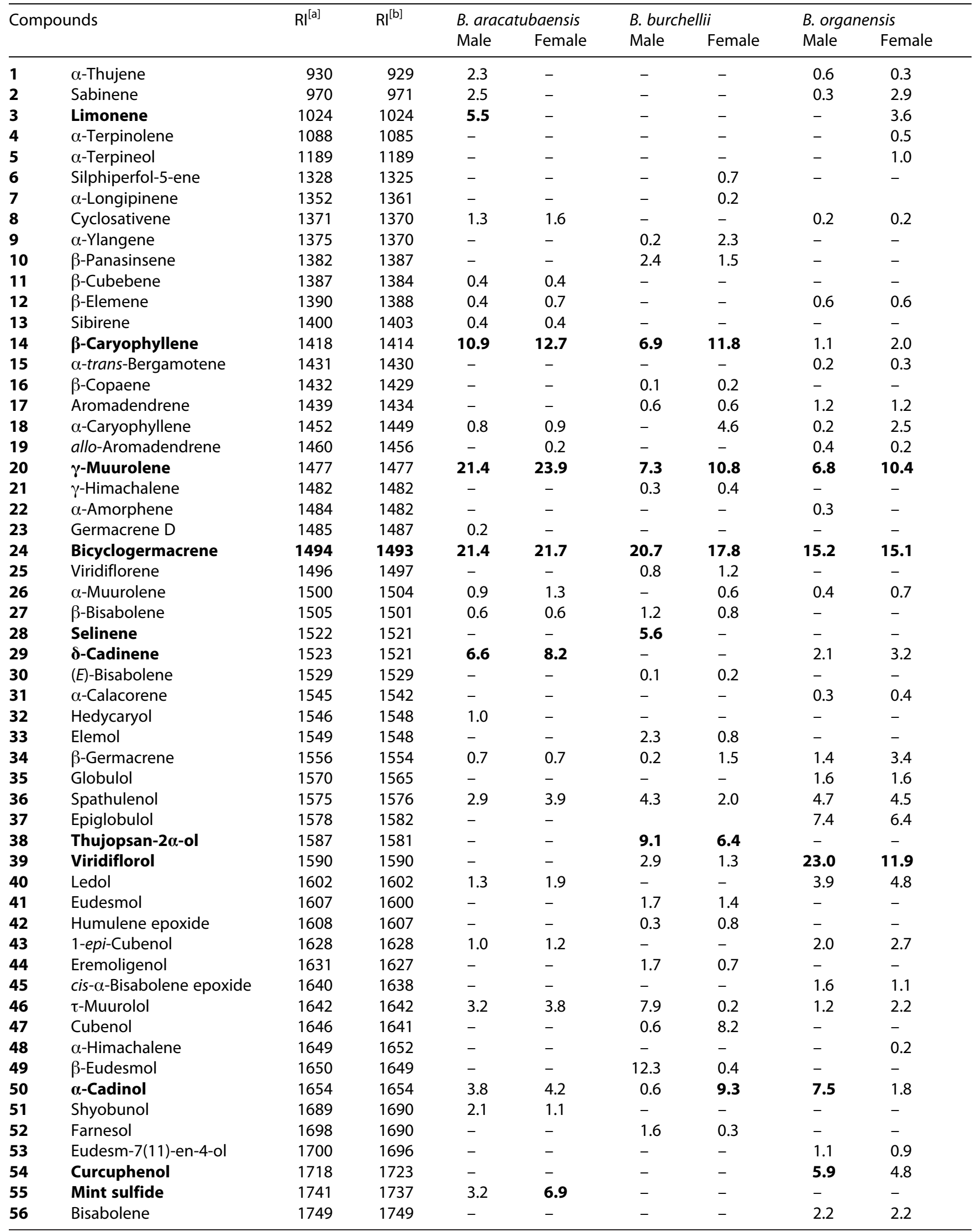


Table 1. (cont.)

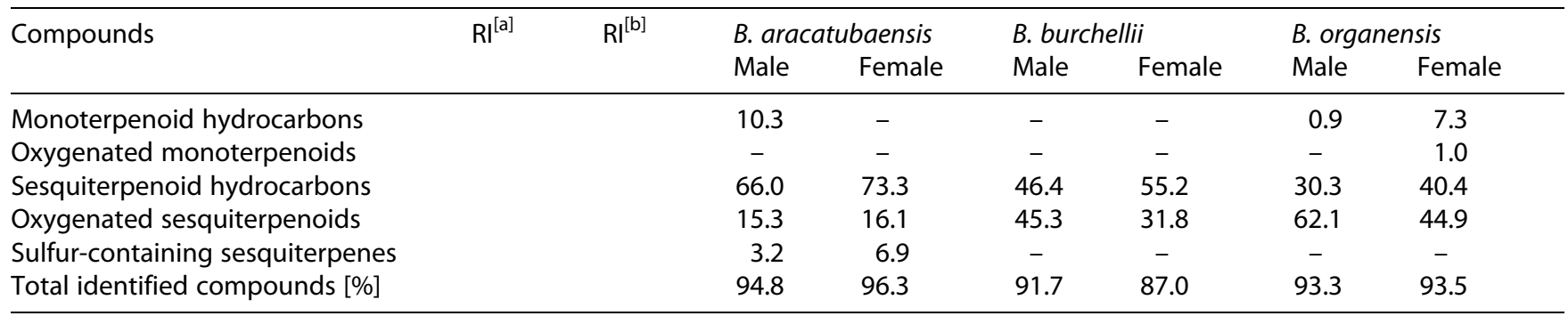

${ }^{[a]} \mathrm{RI}$ (calc.), retention indices on DB-5MS column calculated according to ref. [37].

${ }^{[b]} \mathrm{Rl}$, retention indices according to ref. [38].

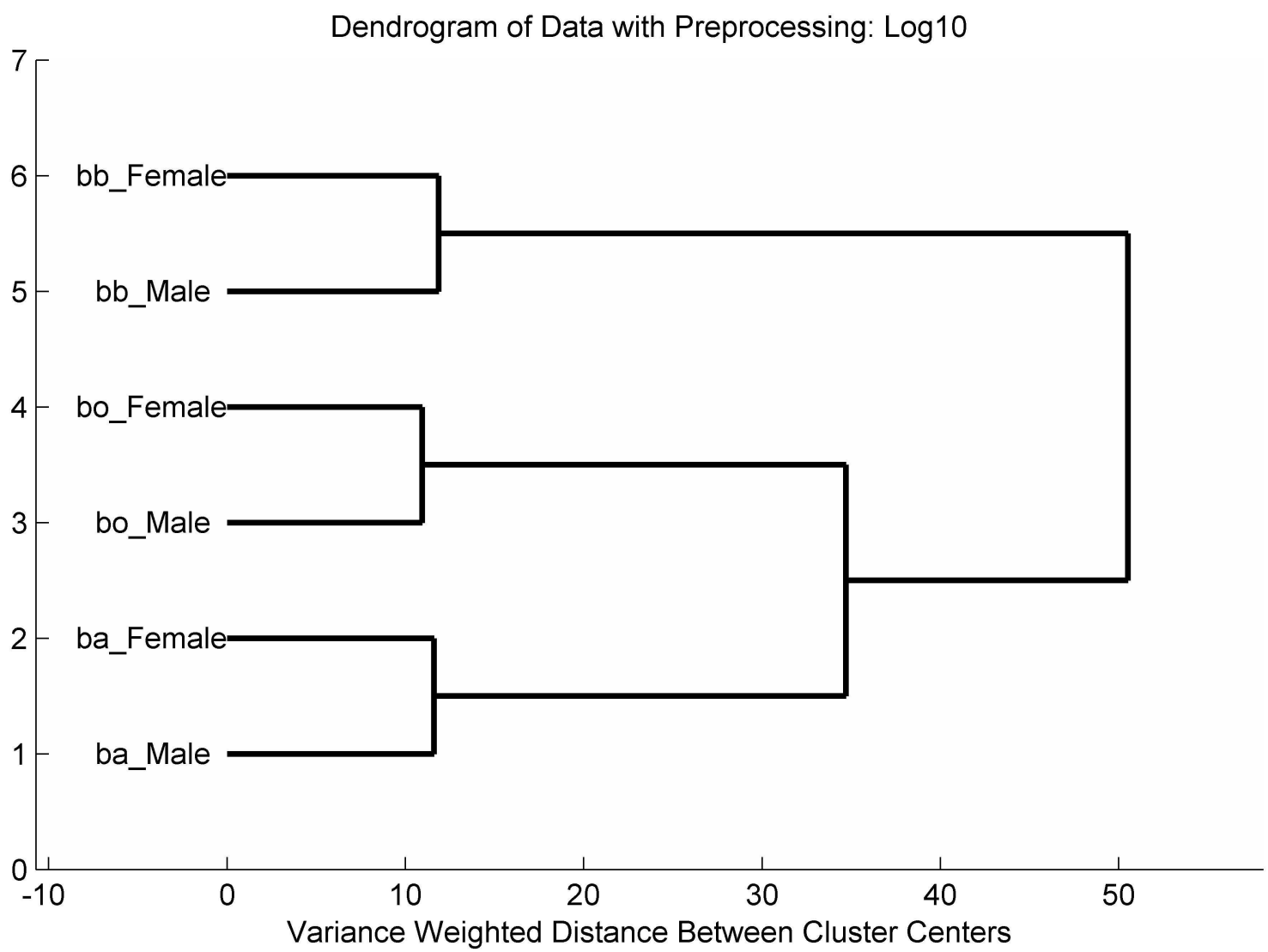

Figure 1. Hierarchical cluster analysis applied to Baccharis aracatubaensis (ba), B. burchellii (bb), and B. organensis (bo) essential oil samples (male and female specimens) using all identified compounds.

environmental conditions. $B$. aracatubaensis and $B$. organensis were collected in mountainous regions above $1000 \mathrm{~m}$ of altitude and under high solar irradiation, while $B$. burchellii was collected from a region with higher humidity (river proximity), lower luminosity, and altitude. In general, the biosynthesis of certain vegetable constituents, especially terpenoids, is genetically determined, but the influence of abiotic factors, such as light, temperature, water, soil, and altitude, has been proven in different species. ${ }^{[43,44]}$

Among the major compounds identified in the essential oils of the analyzed samples, many have been previously reported in other species of the genus Baccharis. ${ }^{[10]}$ The compounds limonene, $\beta$-caryophyllene, $\alpha$-cadinol, bicyclogermacrene, spathulenol, and viridiflorol have been identified in Baccharis uncinella DC. ${ }^{[41,45,46]}$ epiglobulol and $\beta$-eudesmol in $B$. 
trimera; ${ }^{[47]}$ curcuphenol in Baccharis genistelloides (LAM). PERS. ${ }^{[48]} \gamma$-muurolene and $\delta$-cadinene in Baccharis dracunculifolia DC.; ${ }^{[49]}$ and limonene, $\beta$-caryophyllene, $\gamma$-muurolene, bicyclogermacrene, and spathulenol in Baccharis semiserrata DC. ${ }^{[46]}$

A recent study on the chemical composition of essential oils from five Baccharis species showed the presence of $\alpha$-pinene in Baccharis reticularioides DEBLE and A.S. OLIVEIRA; $\alpha$-bisabolol in Baccharis punctulata DC.; spathulenol and kongol in Baccharis microdonta DC., $\beta$-pinene and limonene in Baccharis pauciflosculosa DC., and $\beta$-pinene, limonene, and spathulenol in Baccharis sphenophylla DusÉN ex MALM ${ }^{[19]}$ as the major compounds. These essential oils were extracted from vegetative aerial parts of Baccharis.

The essential oils of these specimens of Baccharis possessed antioxidant/free-radical scavenging effects. The ORAC and DPPH results for the essential oils are summarized in Table 2.

Table 2. Antioxidant assay of the essential oils of male and female specimens from Baccharis aracatubaensis, B. burchellii, and $B$. organensis.

\begin{tabular}{|c|c|c|}
\hline $\begin{array}{l}\text { Samples (essential oil/experimental } \\
\text { control) }\end{array}$ & 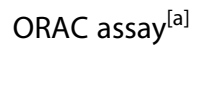 & $\begin{array}{l}\text { DPPH } \\
\text { assay }^{[\mathrm{b}]}\end{array}$ \\
\hline B. aracatubaensis (Male) & $680.6(1.79) \varepsilon$ & Strong \\
\hline B. aracatubaensis (Female) & $536.1(5.87) \varepsilon$ & Medium \\
\hline B. burchellii (Male) & $576.7(2.38) \varepsilon$ & Medium \\
\hline B. burchellii (Female) & $626.0(1.88) \varepsilon$ & Medium \\
\hline B. organensis (Male) & $1202.2(4.77) \omega$ & Strong \\
\hline B. organensis (Female) & $951.4(1.04) \omega$ & Strong \\
\hline$\beta$-Caryophyllene $e^{[c]}$ & $1.4(0.60)^{\prime}$ & Strong \\
\hline Bicyclogermacrene $e^{[c]}$ & $1.2(0.50)^{1}$ & Strong \\
\hline Limonene $^{[c]}$ & $2.0(1.10)^{\prime \prime}$ & Strong \\
\hline$\alpha$-Terpineol ${ }^{[c]}$ & $2.6(1.20)^{I I}$ & Strong \\
\hline Quercetin ${ }^{[c]}$ & $5.5(1.50)^{111}$ & Strong \\
\hline
\end{tabular}

[a] ORAC data expressed as $\mu \mathrm{mol}$ of Trolox equivalents per $\mathrm{g}$ of essential oil ( $\mu \mathrm{mol}$ of TE $\mathrm{g}^{-1}$ ), mean (\% RSD, relative standard deviation) of triplicate assays. ${ }^{[b]}$ TLC-based 1,1-diphenyl-2picrylhydrazyl (DPPH) radical scavenger antioxidant assay. [c] Positive experimental controls (Sigma-Aldrich) with ORAC data expressed as relative Trolox equivalent, mean (\% RSD, relative standard deviation) of triplicate assays. Statistics: $(\varepsilon \neq \omega)$ and $(I \neq I \neq I I), P<0.001$ (ANOVA and Tukey's post-hoc test).

In TLC autographic assay for DPPH radical scavenging (qualitative method), all samples produced yellow spots after the DPPH reagent was sprayed, suggesting antioxidant activity for these essential oils at 1:250 (v/ v) dilution. In $\mathrm{ORAC}_{\mathrm{FL}}$ assay (quantitative method), the criteria used for interpretation of results of antioxidant capacity was: mixtures of compounds such as extracts and essential oils possess high antioxidant capacity with results in $\mathrm{ORAC}_{\mathrm{FL}}$ assay $\geq 800.0 \mu \mathrm{mol}$ of Trolox equivalent (TE) $\mathrm{g}^{-1}$ and isolated compounds with values of $\geq 1.0$ relative Trolox equivalent (RTE). ${ }^{[50-52]}$ All samples tested showed antioxidant capacity greater than $500.0 \mu \mathrm{molTEg}^{-1}$. In these essential oils were found $\beta$-caryophyllene, bicyclogermacrene, limonene, and $\alpha$-terpineol compounds, and according to the literature, these are known for their potent antioxidant activity and commonly found in the composition of essential oils. ${ }^{[53-56]}$

Few studies have reported the antioxidant and antimicrobial activities of the essential oils of Baccharis. ${ }^{[10]}$ Of the three species analyzed in this study, only $B$. burchellii has been reported to have antioxidant activity, however, the study was performed from the crude extract of the aerial parts. ${ }^{[57]}$ The oil of $B$. uncinella showed inhibition in the formation of reactive oxygen species when assessed by the coupled oxidation of $\beta$-carotene and linoleic acid. ${ }^{[26]}$ B. dracunculifolia and Baccharis trinervis PERS. showed inhibition in the formation of reactive oxygen species when assessed by the coupled oxidation of $\beta$-carotene and linoleic acid and DPPH assays. ${ }^{[18,26,58]}$ The essential oil from Baccharis tridentata $V_{A H L}$ showed no significant antioxidant activity against the coupled oxidation of $\beta$ carotene and linoleic acid and DPPH assays. ${ }^{[59]}$

The antioxidant properties of essential oils from several plants have been evaluated using $\mathrm{ORAC}_{\mathrm{FL}}$ and DPPH assays in previous studies, and in these oils, $\gamma$ muurolene, $\delta$-cadinene, germacrene $D$, bicyclogermacrene, $\alpha$-copaene, and $(\beta)$-caryophyllene were found to be the major components. ${ }^{[51]}$ In addition, significant in vitro antioxidant activities in the $\mathrm{ORAC}_{\mathrm{FL}}$ and $\mathrm{DPPH}$ assays were documented for the essential oils extracted from the leaves of Annona salzmannii A.DC. and Annona pickelii (Diels) H.RAINER (Annonaceae), and sesquiterpenes predominated in both essential oils, with bicyclogermacrene, $\beta$-caryophyllene, $\alpha$-copaene, germacrene $D$, and $\delta$-cadinene $e^{[50]}$ as main components. Therefore, the antioxidant capacity observed in the present study is also attributed to the sesquiterpenes from the essential oils of these Baccharis species. The highest antioxidant activity was observed for the essential oils from B. organensis (900-1203 $\mu \mathrm{mol}$ of $\mathrm{TEg}^{-1}$ ), and this demonstrates the major chemistry diversity, as about 33 compounds were identified in the essential oils from this species, being the sesquiterpenes as predominant class. This activity has been attributed to the complex essential oils and rarely to isolated compounds. ${ }^{[24]}$ The compounds curcuphenol, $\alpha$-terpineol, epiglobulol, bisabolene, eu- 
Table 3. Antimicrobial activity of the essential oils of male and female specimens from Baccharis aracatubaensis, $B$. burchellii, and $B$. organensis.

\begin{tabular}{|c|c|c|c|c|}
\hline Microorganism & B. aracatubaensis $^{[\mathrm{a}]}$ & B. burchelliii ${ }^{[\mathrm{a}]}$ & B. organensis ${ }^{[\mathrm{a}]}$ & Controls $^{[\mathrm{b}]}$ \\
\hline E. coli (ATCC 8738) & $>1000$ & $>1000$ & $>1000$ & 100 \\
\hline C. albicans (ATCC 10231) & $>1000$ & $>1000$ & $>1000$ & 500 \\
\hline
\end{tabular}

${ }^{[a]}$ Concentrations are expressed in $\mu \mathrm{g} \mathrm{mL}^{-1}$. ${ }^{[b]}$ Positive controls: chloramphenicol for bacterial strains and ketoconazole for yeast strains.

desm-7(11)-en-4-ol, cis- $\alpha$-bisabolene epoxide, and globulol were identified only in $B$. organensis, suggesting that a possible synergism might be involved among the main components or with other minor components, as the essential oils are a complex mixture of components. ${ }^{[60]}$

To the best of our knowledge, this is the first report on the analysis of the constituents of the essential oils of $B$. aracatubaensis, B. burchellii, and B. organensis, and their antioxidant activity. The chemical compositions of these essential oils are in agreement with the chemistry of the oils reported previously in another species of Baccharis. The strong $\left(\geq 800.0 \mu \mathrm{molTEg}^{-1}\right)$ antioxidant activity of the essential oils obtained from Baccharis specimens studied suggests their potential as a natural source of biologically active compounds.

Many of these compounds show promising biological activities; ${ }^{[10]}$ for instance, bicyclogermacrene, cubenol, and epiglobulol show antibacterial activity, ${ }^{[61-63]}$ while viridiflorol and curcuphenol show antifungal activity. ${ }^{[64,65]}$ Thus, the investigation of the antioxidant activity of the essential oils obtained from Baccharis species analyzed is crucial for the development of new pharmacologic agents for the treatment of diseases.

Antioxidant activity is related to a series of other activities $^{[66-68]}$ and the positive antioxidant results observed in the present study motivated us to perform the antimicrobial assay. However, no antimicrobial activity was observed against Staphylococcus aureus, Escherichia coli, Pseudomonas aeruginosa, and Candida albicans strains, as shown in Table 3.

Some species of Baccharis such as $B$. dracunculifolia ${ }^{[18,69]}$ and $B$. uncinell ${ }^{[46]}$ did not exhibit any antimicrobial activity. B. semiserrata showed weak antimicrobial activity for $S$. aureus. ${ }^{[46]}$ The negative results obtained for $B$. aracatubaensis, $B$. burchellii, and $B$. organensis may be associated with little or no presence of monoterpenes in the essential oils. According to the results obtained by Miranda et al.
(2016), the essential oils with higher content of monoterpenes were more effective at inhibiting bacterial growth than essential oils rich in sesquiterpenes. ${ }^{[18]}$ The antibacterial activity presented by oils rich in monoterpenes can be justified by the ability of these compounds to reach the cytoplasm of bacteria, through the pore proteins in their outer membrane. ${ }^{[70]}$

In this study, we examined the anatomical characteristics of the secretory structures of $B$. aracatubaensis, $B$. burchellii, and $B$. organensis to determine the essential oil storage and pharmacobotanical characters of the taxon. Baccharis species are volatile oil producers and it is common to find glandular trichomes and secretory ducts in aerial vegetative organs, ${ }^{[6]}$ as found in the species studied. Glandular trichomes and secretory ducts are secretory structures which produce and compartmentalize the volatile oils. $^{[71]}$ The biseriate and flagelliform types are the most common glandular trichomes present in Baccharis. ${ }^{[9]}$ Considering the flagelliform glandular trichomes, besides their covering role, they may have secretory function, as observed in Baccharis pentaptera (LESS.) DC., ${ }^{[72]}$ Baccharis illinita DC., B. microdonta, B. pauciflosculosa, $B$. reticularioides, and $B$. sphenophylla. ${ }^{[9]}$

In the present study, secretory ducts (Figures $2 A$, $2 C, 2 D, 2 F$, and $2 G$ ) and flagelliform glandular trichomes (Figures 2B, 2E) were observed in all the Baccharis specimens studied. Secretory ducts were found in the mesophyll (Figures $2 A, 2 G$ ) and midrib (Figures 2C, 2F) of the leaves. They were composed of 6-20 cells with a uniseriate epithelium, dense cytoplasm, evident nucleus, and lipophilic content found next to the endodermis in the direction of the phloem (Figures 2A, 2C, 2F, 2G). In the stem, the secretory ducts are found next to the endoderm that binds the internal part of the cortex (Figure 2D), and its walls are impregnated with lipophilic compounds. Additionally, three secretory ducts were found to meet near the phloem in the midrib of $B$. organensis (Figure 2F). The 


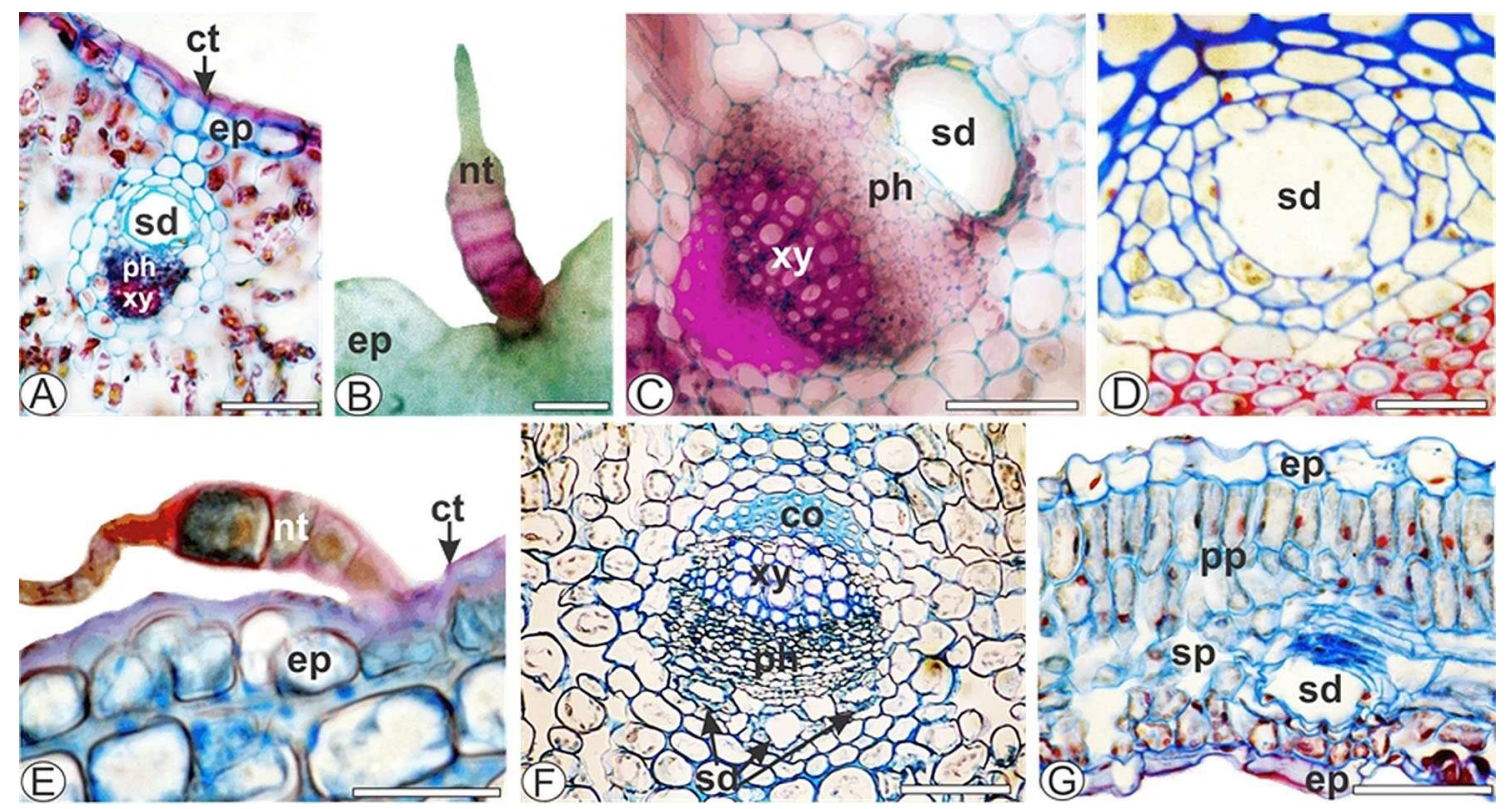

Figure 2. Aerial vegetative organs of Baccharis aracatubaensis, B. burchellii, and B. organensis. A), B), and C) - Baccharis aracatubaensis; D), E), F) - Baccharis organensis, and G) - Baccharis burchellii. A) Leaf in cross-section showing cuticle (cu), epidermis (ep), phloem (ph), secretory duct (sd), and xylem (xy). B) Frontal view of the leaf epidermis (ep) indicating the flagelliform glandular trichome (nt). C) Midrib of the leaf in cross-section showing phloem (ph), secretory duct (sd), and xylem (xy). D) Stem in crosssection indicating a secretory duct (sd). E) Stem in cross-section showing cuticle (cu), epidermis (ep), and flagelliform glandular trichome (gt). F) Midrib of the leaf in cross-section indicating collenchyma (co), phloem (ph), secretory ducts (sd), and xylem (xy). G). Leaf in cross-section indicating epidermis (ep), secretory duct (sd), spongy parenchyma (sp), and palisade parenchyma (pp). Scale bar $=50 \mu \mathrm{m}(\mathrm{A}, \mathrm{B}, \mathrm{C}, \mathrm{D}, \mathrm{F}, \mathrm{G}), 12.5 \mu \mathrm{m}(\mathrm{E})$.

presence of three secretory ducts in the midrib can be used to differentiate $B$. organensis from $B$. aracatubaensis and B. burchellii. This characteristic is not frequently observed in Baccharis species. ${ }^{[8,9]}$ This characteristic may be helpful in quality control.

The flagelliform glandular trichomes were found in a small depression of the epidermis of the leaves (Figure 2B) and stems (Figure 2E). Oil droplets and secretory substances were observed visually under the microscope and also were confirmed by histochemical tests, in the body (Figures 2B, 2E), head cells as well as the tubular apical cells.

To the best of our knowledge, this is the first study that evaluates the chemical, antioxidant, and antimicrobial characteristics of the essential oils and anatomy of the aerial parts of female and male specimens from B. aracatubaensis, B. burchellii, and B. organensis, as part of the chemical, biological and anatomical studies of Baccharis species realized by our group of research. ${ }^{[7,74]}$ The chemical composition of these essential oils is in agreement with the chemistry of the oils reported previously in another species from the genus Baccharis, with sesquiterpenes as a major component. The high antioxidant activity of the essential oils of Baccharis specimens studied suggests their potential as a natural source of biologically active compounds. The anatomical study of the aerial vegetative organs corroborates the findings from the studies of other Baccharis species. This is the first report regarding the collection and identification of female and male specimens from B. burchellii in Paraná State, Brazil. This study also confirms the importance of chemical and biological investigations of essential oils of Baccharis species (Asteraceae) in the search for new and safer bioactive agents. However, further investigations are necessary to confirm the potential of Baccharis essential oils as bioactive product useful for in vivo applications.

\section{Experimental Section}

\section{Collection of Plant Material}

Botanical material of male and female specimens of Baccharis were collected separately and randomly along a transect within the same population in November 2013 in the 'Morro do Canal', Municipality of Piraquara, Paraná State, Brazil. The inflorescences 
were collected from B. aracatubaensis $\left(25^{\circ} 30^{\prime} 52-48^{\prime \prime}\right.$ $\left.\mathrm{S} / 48^{\circ} 59^{\prime} 10-41^{\prime \prime} \mathrm{O}\right)$ and B. organensis $\left(25^{\circ} 30^{\prime} 52-39^{\prime \prime} \mathrm{S} /\right.$ $48^{\circ} 59^{\prime} 10-78^{\prime \prime}$ O) samples, at an elevation of $1200-$ $1300 \mathrm{~m}$. The inflorescences from $B$. burchellii samples were collected in proximity of one river $\left(25^{\circ} 31^{\prime} 11-54^{\prime \prime}\right.$ $\left.\mathrm{S} / 49^{\circ} 00^{\prime} 21-17^{\prime \prime} \mathrm{O}\right)$ at an elevation of $906 \mathrm{~m}$. The species were identified by botanists Osmar dos Santos Ribas, Dr. Gustavo Heiden and Dr. Angelo Alberto Schneider. The voucher specimens were deposited with the Botanical Museum of Curitiba (MBM), under the numbers: (MBM-286268/MBM-286267), (MBM386275/MBM-386266), and (MBM-386257/MBM386256), respectively. ${ }^{[75]}$

The access to the botanical material was authorized and licensed by the 'Ministério do Meio Ambiente Sistema Nacional de Gestão do Patrimônio Genético e do Conhecimento Tradicional Associado' (SisGen) and registered under No. A7A6DCC.

\section{Hydrodistillation of Essential Oils}

The essential oil of the inflorescences from $B$. aracatubaensis, B. burchellii, and $B$. organensis was isolated by hydrodistillation using $100-150 \mathrm{~g}$ of each fresh plant material and 1.0-1.5 L of distilled water, for $3 \mathrm{~h}$, using a Clevenger-type apparatus according to the method recommended in Brazilian Pharmacopeia 5th edn. ${ }^{[76]}$ The distillated oil was extracted twice with ethyl ether and dried over anhydrous sodium sulfate, the excess solvent was withdrawn using nitrogen flow. The yield of each essential oil was calculated based on the weight of essential oil and the weight of the plant material, which was then stored in tightly closed dark vials at $4{ }^{\circ} \mathrm{C}$ until analysis.

GC/MS analyses were performed using a Shimadzu Model GC/MS-QP 2010 Plus apparatus equipped with an AOC-20i auto-injector, as per the method described by Costa et al. with some modifications. ${ }^{[50]}$ The chromatograph was equipped with a ZB-5MS Phenomenex Zebron column $(30 \times 0.25 \mathrm{~mm}, 0.25 \mathrm{~mm})$. The samples were injected at a 1:30 split ratio, and the analysis conditions were as follows: Sample concentration at $1: 100(\mu \mathrm{L})$ in $\mathrm{CH}_{2} \mathrm{Cl}_{2}$, injection volume of $1.0 \mu \mathrm{L}$, temperature of the injector $240^{\circ} \mathrm{C}$. The oven temperature was programmed to $40^{\circ} \mathrm{C} / 4 \mathrm{~min}$, followed by increase with a rate of $4^{\circ} \mathrm{C} / \mathrm{min}$ to $240^{\circ} \mathrm{C}$, then by $10^{\circ} \mathrm{C} / \mathrm{min}$ up to $280^{\circ} \mathrm{C}$, and temperature of $280^{\circ} \mathrm{C} / 2 \mathrm{~min} ; 60 \mathrm{~min}$ chromatographic run.
The retention indices for all the compounds were determined by injecting a standard solution containing the homologous series of $n$-alkanes $\left(C_{8}-C_{18}\right)$. The calculation of peak area percentage was carried out by using the GC/MS Lab Solutions software (Shimadzu). Individual constituents were identified by the comparison of their mass spectra (MS) and retention indices (RI) with those reported in literature ${ }^{[37,38]}$ and also in National Institute of Standards and Technology (NIST) mass spectral database.

\section{Antioxidant Activity}

ORAC $F L_{F}$ Kinetic Assay. The antioxidant capacities of the essential oils of $B$. aracatubaensis, $B$. burchellii, and $B$. organensis were assessed through the oxygen radical absorbance capacity (ORAC) assay. The automated ORAC assay was performed on a Synergy 2 (Biotek, Winooski, VT) multidetection microplate reader system. The procedure was carried out according to the method already established by $\mathrm{Ou}$ et al. ${ }^{[52]}$ with modifications and Costa et al. ${ }^{[51]}$ The results were calculated using the differences of areas under the fluorescein (FL) decay curves between the blank and a sample and were expressed as mean (\% RSD, relative standard deviation) of triplicate assays in micromole of Trolox equivalents (TE) per gram ( $\mu \mathrm{mol}$ of $\mathrm{TE} \mathrm{g}^{-1}$ ) for essential oils tested and as relative Trolox equivalent (RTE) for standardized samples (Sigma-Aldrich) used as positive experimental controls.

TLC Autographic Assay for DPPH Radical Scavenging. The DPPH test allows the evaluation of hijacking the free radical, the purple coloration, by action of an antioxidant species present in the sample, by undergoing reduction to form yellow colored 2,2-diphenyl1-picrylhydrazine $(\mathrm{DPPH}-\mathrm{H}){ }^{[77]}$ The procedure was carried out according to the method described by Costa et al., ${ }^{[50]}$ and the interpretation of results was performed as described by Takamatsu et al. ${ }^{[78]}$ The samples that presented antioxidant activity produced yellowish spots and were classified according to the intensity of the yellow spots produced.

Samples with strong or high antioxidant activity presented an intense bright yellow spot, samples with medium antioxidant activity presented with a light yellow stain, samples with weak antioxidant activity showed a weak yellow stain or samples without antioxidant activity where devoid of yellowish coloration. $^{[78]}$ 


\section{Antimicrobial Assay}

The antimicrobial assay of the essential oils (male and female specimens) from $B$. organensis, $B$. burchellii, and $B$. aracatubaensis was performed using Clinical and Laboratory Standards Institute (CSLI) microdilution method. ${ }^{[79]}$ The oils were carried out against Staphylococcus aureus (ATCC 6538), Escherichia coli (ATCC 8738), Pseudomonas aeruginosa (ATCC 9027), and Candida albicans (ATCC 10231).

The microorganism suspensions used for inoculation were prepared at $10^{5}$ CFU (colony forming unit/ $\mathrm{mL}$ ) by diluting fresh cultures at McFarland 0.5 density. As positive controls were used $100 \mu \mathrm{g} \mathrm{mL}^{-1}$ of chloramphenicol for the bacteria and $500 \mu \mathrm{g} \mathrm{mL}^{-1}$ of ketoconazole for the yeast. The essential oils were solubilized with $5 \%$ of DMSO and $\mathrm{H}_{2} \mathrm{O}$, to adjust the concentrations to $100 \mu \mathrm{g} \mathrm{mL}^{-1}$. The minimal inhibitory concentration (MIC) was defined as the lowest extract concentration showing no visible bacterial growth after incubation time, and the absorbance was measured in spectrophotometer to $540 \mathrm{~nm}$.

\section{Anatomical Study}

At least six samples of mature leaves of $B$. aracatubaensis, B. burchellii, and B. organensis (male and female) were obtained from the sixth node and below, as well as stem fragments 5 to $15 \mathrm{~cm}$ from the shoot were collected to anatomical analyses. The plant materials were fixed in FAA $70^{[80]}$ and kept in $70 \%$ ethanol solution. ${ }^{[81]}$ These materials were sectioned by hand or dehydrated, embedded in glycol methacrylate (Leica Historesin ${ }^{\circledR}$ ) and sectioned using the Leica RM2145 microtome. Transverse and longitudinal sections were stained with astra blue and basic fuchsine combination. ${ }^{[82]}$ The samples were clarified in frontal view of the epidermis. ${ }^{[83]}$ Moreover, in order to show where the lipophilic compounds were located, Sudan III was used. ${ }^{[84]}$ The photomicrographs were captured by an Olympus CX31 light microscope equipped with a C7070 control unit.

\section{Statistical Analysis}

The essential oil composition of the specimens was analyzed by hierarchical cluster analysis (HCA). The data were transformed with Log10 and the Ward's method as the amalgamation rule and Euclidean distances as metric were used to generate a dendrogram for the samples.
The analysis of the results obtained in the antioxidant assay was presented as mean (\% RSD, relative standard deviation). Comparisons of the groups were evaluated by analyses of variance (one-way ANOVA), followed by the Tukey's post-hoc test. Differences were considered to be significant at $P<0.001$.

\section{Acknowledgements}

The authors thank CAPES, CNPq, UFPR, Fundação Araucária, FAPEAM, and FAPESP for financial support and fellowships, MBM for collection of botanical material, Dr. Angelo Alberto Schneider (UNIPAMPA-RS) for $B$. burchellii identification, the 'Ministério do Meio Ambiente - Sistema Nacional de Gestão do Patrimônio Genético e do Conhecimento Tradicional Associado' (SisGen) for registration of genetic material (No. A7A6DCC).

\section{Author Contribution Statement}

T.Z. and F.R.C. wrote the article. T.Z., J.B., and A.V.F.L. conducted fieldwork and collection of the samples, besides analyzed and prepared the data for the manuscript. G.H. identified the plant samples. A.V. and F.S.M. guided the antimicrobial assays. M.J.S. and J.V.N.M. guided the antioxidant assays and contributed to the analysis of the data. J.M.B. and P.A.R. performed the micromorphology experiments, evaluated, and analyzed the anatomy data. E.B., T.Z., and F.R.C. performed the statistical analysis.

\section{References}

[1] J. L. Panero, V. A. Funk, 'The value of sampling anomalous taxa in phylogenetic studies: Major clades of the Asteraceae revealed', Mol. Phylogenet. Evol. 2008, 47, 757-782.

[2] M. J. Abad, P. Bermejo, 'Baccharis (Compositae): a review update', Arkivoc 2006, 7, 76-96.

[3] http://floradobrasil.jbrj.gov.br/reflora/listaBrasil/FichaPublicaTaxonUC/FichaPublicaTaxonUC.do?id =FB5151, Accessed January 10, 2017. Botânico do Rio de Janeiro.

[4] G. M. Barroso, O. L. Bueno, 'Compostas-Subtribo: Baccharidinae', Itajai-SC, Ministério do Meio Ambiente, 2002.

[5] G. Heiden, J. R. V. Iganci, L. Macias, 'Baccharis sect. Caulopterae (Asteraceae, Astereae) no Rio Grande do Sul, Brasil', Rodriguesia 2009, 60, 943-983.

[6] J. M. Budel, M. R. Duarte, P. M. Döll-Boscardin, P. V. Farago, N. I. Matzenbacher, A. Sartoratto, B. H. L. N. S. Maia, 'Composition of essential oils and secretory structures of Baccharis anomala, B. megapotamica and B. ochracea', J. Essent. Oil Res. 2012, 24, 19-24. 
[7] V. C. G. Jasinski, R. Z. da Silva, R. Pontarolo, J. M. Budel, F. R. Campos, 'Morpho-anatomical characteristics of Baccharis glaziovii in support of its pharmacobotany', Rev. Bras. Farmacogn. 2014, 24, 609-616.

[8] V. B. Bobek, G. Heiden, C. F. de Oliveira, V. P. de Almeida, J.P. de Paula, P. V. Farago, T. Nakashima, J. M. Budel, 'Comparative analytical micrographs of 'vassouras' (Baccharis, Asteraceae)', Rev. Bras. Farmacogn. 2016, 26, 665-672.

[9] J. M. Budel, V. Raman, L. M. Monteiro, V. P. Almeida, V. B. Bobek, G. Heiden, I. J. M. Takeda, I. A. Khan, 'Foliar anatomy and microscopy of six Brazilian species of Baccharis (Asteraceae)', Microsc. Res. Tech. 2018, 81, 832-842.

[10] F. R. Campos, J. Bressan, V. C. G. Jasinski, T. Zuccolotto, L. E. da Silva, L. B. Cerqueira, 'Baccharis (Asteraceae): Chemical Constituents and Biological Activities', Chem. Biodiversity 2016, 13, 1-17.

[11] M. A. Besten, V. C. G. Jasinski, A. de G. L. C. Costa, D. S. Nunes, S. L. Sens, A. Wisniewski Jr., E. L. Simionatto, D. Riva, J. B. Dalmarco, D. Granato, 'Chemical composition similarity between the essential oils isolated from male and female specimens of each five Baccharis species', J. Braz. Chem. Soc. 2012, 23, $1041-1047$.

[12] M. A. Besten, D. S. Nunes, A. Wisniewski Jr., S. L. Sens, D. Granato, E. L. Simionatto, D. R. Scharf, J. B. Dalmarco, N. I. Matzenbacher, 'Chemical composition of volatiles from male and female specimens of Baccharis trimera collected in two distant regions of southern brazil: a comparative study using chemometrics', Quim. Nova 2013, 36, 10961100.

[13] M. A. Besten, D. S. Nunes, D. Granato, S. L. Sens, A. Wisniewski Jr., E. L. Simionatto, D. R. Scharf, 'Chemical Composition of Essential Oils from Cladodes and Inflorescences from Male and Female Specimens of Baccharis milleflora', J. Essent. Oil-Bear. Plants 2014, 17, 899-905.

[14] F. Bakkali, S. Averbeck, D. Averbeck, M. Idaomar, 'Biological effects of essential oils-A review', Food Chem. Toxicol. 2008, 46, 446-475.

[15] M. T. Salles Trevisan, F. V. Viana Macedo, M. van de Meent, I. K. Rhee, R. Verpoorte, 'Seleção de plantas com atividade anticolinasterase para tratamento da doença de Alzheimer', Quim. Nova 2003, 26, 301-304.

[16] M. Lahlou, 'Methods to Study the Phytochemistry and Bioactivity of Essential Oils', Phytoterapy Res. 2004, 18, $435-448$.

[17] A. T. Henriques, C. A. Simões-Pires, M. A. Apel, in 'Química de produtos naturais, novos fármacos e a moderna farmacognosia', Ed. Univali, Itajaí, 2009, p. 219.

[18] C. A. S. F. Miranda, M. das G. Cardoso, L. R. Batista, L. M. A. Rodrigues, A.C. da S. Figueiredo, 'Óleos essenciais de folhas de diversas espécies: propriedades antioxidantes e antibacterianas no crescimento espécies patogênicas', Rev. Ciência Agronômica 2016, 47, 213-220.

[19] J. M. Budel, M. Wang, V. Raman, J. Zhao, S. I. Khan, J. U. Rehman, N. Techen, B. Tekwani, L. M. Monteiro, G. Heiden, I. J. M. Takeda, P. V. Farago, I. A. Khan, 'Essential Oils of Five Baccharis Species: Investigations on the Chemical Composition and Biological Activities', Molecules 2018, 23, 1-19.

[20] M. L. Cohen, 'Epidemiology of Drug Resistance: Implications for a Post-Antimicrobial Era', Science 1992, 257, 1050-1055.
[21] J. A. Amaral, A. Ekins, S. R. Richards, R. Knowles, 'Effect of Selected Monoterpenes on Methane Oxidation, Denitrification, and Aerobic Metabolism by Bacteria in Pure Culture', Appl. Environ. Microbiol. 1998, 64, 520-525.

[22] M. B. Arnao, 'Some methodological problems in the determination of antioxidant activity using chromogen radicals: a practical case', Trends Food Sci. Technol. 2000, 11, 419-421.

[23] G. G. F. Nascimento, J. Locatelli, P. C. Freitas, G. L. Silva, 'Antibacterial Activity of Plant Extracts and Phytochemicals on Antibiotic', Braz. J. Microbiol. 2000, 31, 247-256.

[24] F. Candan, M. Unlu, B. Tepe, D. Daferera, M. Polissiou, A. Sökmen, H. A. Akpulat, 'Antioxidant and antimicrobial activity of the essential oil and methanol extracts of Achillea millefolium subsp. millefolium Afan. (Asteraceae)', J. Ethnopharmacol. 2003, 87, 215-220.

[25] G. Sacchetti, S. Maietti, M. Muzzoli, M. Scaglianti, S. Manfredini, M. Radice, R. Bruni, 'Comparative evaluation of 11 essential oils of different origin as functional antioxidants, antiradicals and antimicrobials in foods', Food Chem. 2005, 91, 621-632.

[26] R. Ferronatto, E. D. Marchesan, F. Bednarski, S. M. de Alencar, S. B. Onofre, 'Atividade antioxidante dos óleos essenciais produzidos por Baccharis dracunculifolia D. C. e Baccaris uncinella D. C. (Asteraceae)', Arq. Ciências da Saúde da UNIPAR 2006, 10, 67-70.

[27] K.-A. Seo, H. Kim, H.-Y. Ku, H.-J. Ahn, S.-J. Park, S. K. Bae, J.G. Shin, K.-H. Liu, 'The monoterpenoids citral and geraniol are moderate inhibitors of CYP2B6 hydroxylase activity', Chem.-Biol. Interact. 2008, 174, 141-146.

[28] M. A. Andrade, M. Cardoso, L. R. Batista, A. C. T. Mallet, S. M. Machado, 'Essential oils of Cinnamomum zeylanicum, Cymbopogon nardus and Zingiber officinale: Composition, antioxidant and antibacterial activities', Rev. Cienc. Agron. 2012, 43, 399-408.

[29] G. Lang, G. Buchbauer, 'A review on recent research results (2008-2010) on essential oils as antimicrobials and antifungals. A review', Flavour Fragrance J. 2012, 27, 1339.

[30] D. A. dos Santos, M. de J. Fukui, N. P. D. Nanayakkara, S. I. Khan, J.P. B. Sousa, J. K. Bastos, S. F. Andrade, A. A. da Silva Filho, N. L. M. Quintão, 'Anti-inflammatory and antinociceptive effects of Baccharis dracunculifolia DC. (Asteraceae) in different experimental models', J. Ethnopharmacol. 2010, 127, 543-550.

[31] A. S. G. Figueiredo-Rinhel, L. M. Kabeya, P. C. P. Bueno, R. F. Jorge-Tiossi, A. E. C. S. Azzolini, J. K. Bastos, Y. M. LucisanoValim, 'Inhibition of the human neutrophil oxidative metabolism by Baccharis dracunculifolia DC. (Asteraceae) is influenced by seasonality and the ratio of caffeic acid to other phenolic compounds', J. Ethnopharmacol. 2013, 150, 655-664.

[32] L. G. Verdi, I. M. C. Brighente, M. G. Pizzolatti, 'Gênero Baccharis (Asteraceae): Aspectos químicos, econômicos e biológicos', Quim. Nova 2005, 28, 85-94.

[33] B. B. Jarvis, N. Mokhtari-Rejali, E. P. Schenkel, C. S. Barros, N. I. Matzenbacher, 'Trichothecene mycotoxins from Brazilian Baccharis species', Phytochemistry 1991, 30, 789-797.

[34] L. C. Di Stasi, G. P. Oliveira, M. A. Carvalhaes, M. QueirozJunior, O.S. Tien, S. H. Kakinami, M.S. Reis, 'Medicinal 
plants popularly used in the Brazilian Tropical Atlantic Forest', Fitoterapia 2002, 73, 69-91.

[35] M. G. L. Brandão, G.P. Cosenza, R. A. Moreira, R. L. M. Monte-Mor, 'Medicinal plants and other botanical products from the Brazilian Official Pharmacopoeia', Rev. Bras. Farmacogn. 2006, 16, 408-420.

[36] T. K. Karam, L. M. Dalposso, D. M. Casa, G. B. R. De Freitas, 'Carqueja (Baccharis trimera): utilização terapêutica e biossíntese', Rev. Bras. Plant. Med. 2013, 15, 280-286.

[37] H. van Den Dool, P. D. Kratz, 'A generalization of the retention index system including linear temperature programmed gas-liquid partition chromatography', J. Chromatogr. 1963, 11, 463-471.

[38] R. P. Adams, 'Identification of Essential Oil Components by Gas Cromatography/Mass Spectrometry', Carol Stream, II: Allured Publishing Corporation, 2007.

[39] M. P. Zunino, M. L. López, J. A. Zygadlo, A. G. López, 'Essential Oil Composition of Baccharis articulate (Lam.) Pers.', J. Essent. Oil Res. 2011, 16, 29-30.

[40] A. P. A. Araújo, M. A. A. Carneiro, G. W. Fernandes, 'Efeitos do sexo, do vigor e do tamanho da planta hospedeira sobre a distribuição de insetos indutores de galhas em Baccharis pseudomyriocephala Teodoro (Asteraceae)', Rev. Bras. Entomol. 2003, 47, 483-490.

[41] F. Agostini, A. C. A. Santos, M. Rossato, M. R. Pansera, F. Zattera, R. Wasum, L. A. Serafini, 'Estudo do óleo essencial de algumas espécies do gênero Baccharis (Asteraceae) do sul do Brasil', Rev. Bras. Farmacogn. 2005, 15, 215-220.

[42] J. H. G. Lago, P. Romoff, O. A. Fávero, F. O. Souza, M. G. Soares, P. T. Baraldi, A. G. Corrêa, 'Chemical composition of male and female Baccharis trimera (Less.) DC. (Asteraceae) essential oils', Biochem. Syst. Ecol. 2008, 36, 737-740.

[43] L. A. S. de Morais, 'Influência Dos Fatores Abióticos Na Composição Química Dos Óleos Essenciais', Hortic. Bras. 2009, 27, S4050-S4063.

[44] F. M. C. de Barros, E. de O. Zambarda, B. M. Heinzmann, C. A. Mallmann, 'Variabilidade sazonal e biossíntese de terpenóides presentes no óleo essencial de Lippia alba (Mill.) N. E. Brown (Verbenaceae)', Quim. Nova 2009, 32, $861-867$.

[45] J. Ascari, S. L. Sens, D. S. Nunes, A. Wisniewski Jr., M. D. Arbo, V. M. Linck, P. Lunardi, M. B. Leal, E. Elisabetsky, 'Sedative effects of essential oils obtained from Baccharis uncinella', Pharm. Biol. 2012, 50, 113-119.

[46] A. B. Vannini, T. G. Santos, A. C. Fleming, L. R. P. Purnhagen, L. A. Lourenço, E. T. B. Butzke, M. Kempt, I. M. Begnini, R. A. Rebelo, E. M. Dalmarco, A. Bella Cruz, A. P. Schmit, R. C. B. Cruz, C. N. Yamanaka, M. Steindel, 'Chemical characterization and antimicrobial evaluation of the essential oils from Baccharis uncinella D.C. and Baccharis semiserrata D. C. (Asteraceae)', J. Essent. Oil Res. 2012, 24, 547-554.

[47] C. A. Simões-Pires, S. Debenedetti, E. Spegazzini, L. A. Mentz, N. I. Matzenbacher, R. P. Limberger, A. T. Henriques, 'Investigation of the essential oil from eight species of Baccharis belonging to sect. Caulopterae (Asteraceae, Astereae): a taxonomic approach', Plant Syst. Evol. 2005, $253,23-32$.

[48] A. C. Valdivia, Å. Boketof, B. Olde, C. Owman, A. Vilaseca, L. Fuentes, O. Sterner, 'Activation of the free fatty acid receptor GPR40 by (+)-curcuphenol and related synthetic compounds', Rev. Boliv. Quim. 2009, 26, 77-82.
[49] M. R. Maróstica Jr., A. Daugsch, C. S. Moraes, C. L. Queiroga, G. M. Pastore, Y.K. Parki, 'Comparison of volatile and polyphenolic compounds in Brazilian green propolis and its botanical origin Baccharis dracunculifolia', Ciência e Tecnol. Aliment. 2008, 28, 178-181.

[50] E. V. Costa, L. M. Dutra, H. C. R. de Jesus, P. C. de L. Nogueira, V. R. de S. Moraes, M. J. Salvador, S. C. de H. Cavalcanti, R. L. C. dos Santos, A. P. do N. Prata, 'Chemical Composition and Antioxidant, Antimicrobial, and Larvicidal Activities of the Essential Oils of Annona salzmannii and $A$. pickelli (Annonaceae)', Nat. Prod. Commun. 2011, 6, 907912.

[51] E. V. Costa, T. B. da Silva, L. R. A. Menezes, L. H. G. Ribeiro, F. R. Gadelha, J. E. de Carvalho, L. M. B. de Souza, M. A. N. da Silva, C. A. T. Siqueira, M. J. Salvador, 'Biological activities of the essential oil from the leaves of Xylopia laevigata (Annonaceae)', J. Essent. Oil Res. 2013, 25, 179-185.

[52] B. Ou, D. Huang, M. Hampsch-Woodill, J. A. Flanagan, E. K. Deemer, 'Analysis of Antioxidant Activities of Common Vegetables Employing Oxygen Radical Absorbance Capacity (ORAC) and Ferric Reducing Antioxidant Power (FRAP) Assays: A Comparative Study', J. Agric. Food Chem. 2002, 50, 3122-3128.

[53] M. A. Calleja, J. M. Vieites, T. Montero-Meterdez, M. I. Torres, M. J. Faus, A. Gil, A. Suárez, 'The antioxidant effect of $\beta$ caryophyllene protects rat liver from carbon tetrachlorideinduced fibrosis by inhibiting hepatic stellate cell activation', Br. J. Nutr. 2013, 109, 394-401.

[54] M. A. Farag, D. A. Al-Mahdy, 'Comparative study of the chemical composition and biological activities of Magnolia grandiflora and Magnolia virginiana flower essential oils', Nat. Prod. Res. 2013, 27, 1091 - 1097.

[55] L. Yu, J. Yan, Z. Sun, 'D-Limonene exhibits anti-inflammatory and antioxidant properties in an ulcerative colitis rat model via regulation of iNOS, COX-2, PGE2 and ERK signaling pathways', Mol. Med. Rep. 2017, 15, 2339-2346.

[56] J. L. Bicas, I. A. Neri-Numa, A. L. T. G. Ruiz, J. E. De Carvalho, G. M. Pastore, 'Evaluation of the antioxidant and antiproliferative potential of bioflavors', Food Chem. Toxicol. 2011, 49, 1610-1615.

[57] S. de Oliveira, G. de Souza, C. R. Eckert, T. A. Silva, E. S. Sobral, O. A. Fávero, M. J. P. Ferreira, P. Romoff, W. Josef Baader, 'Evaluation of antiradical assays used in determining the antioxidant capacity of pure compounds and plant extracts', Quim. Nova 2014, 37, 497-503.

[58] A. C. Nogueira Sobrinho, E. B. de Souza, M. F. G. Rocha, M. R. J. R. Albuquerque, P. N. Bandeira, H. S. dos Santos, C. S. de P. Cavalcante, S. S. Oliveira, P. R. Aragão, S. M. de Morais, R. O. dos S. Fontenelle, 'Chemical composition, antioxidant, antifungal and hemolytic activities of essential oil from Baccharis trinervis (Lam.) Pers. (Asteraceae)', Ind. Crops Prod. 2016, 84, 108-115.

[59] S. P. Souza, M. G. Cardoso, P. E. Souza, L. G. L. Guimarães, J. Andrade, A. C. T. Mallet, D. L. Nelson, 'Óleo essencial de Baccharis tridentata Vahl: composição química, atividade antioxidante e fungitóxica, e caracterização morfológica das estruturas secretoras por microscopia eletrônica de varredura', Rev. Bras. Plant. Med. 2011, 13, 456-466.

[60] W. Wang, N. Wu, Y. G. Zu, Y. J. Fu, 'Antioxidative activity of Rosmarinus officinalis $L$. essential oil compared to its main components', Food Chem. 2008, 108, 1019-1022. 
[61] Y.-S. Kim, D.-H. Shin, 'Volatile Constituents from the Leaves of Callicarpa japonica Thunb. and Their Antibacterial Activities', J. Agric. Food Chem. 2004, 52, 781-787.

[62] C. Solís, J. Becerra, C. Flores, J. Robledo, M. Silva, 'Antibacterial and Antifungal Terpenes from Pilgerodendron uviferum (D. DON) Florin', J. Chil. Chem. Soc. 2004, 49, 157161.

[63] T. G. Santos, J. Dognini, I. M. Begnini, R. A. Rebelo, M. Verdi, A. L. de Gasper, E. M. Dalmarco, 'Chemical Characterization of Essential Oils from Drimys angustifolia Miers (Winteraceae) and Antibacterial Activity of their Major Compounds', J. Braz. Chem. Soc. 2013, 24, 164-170.

[64] H. J. M. Gijsen, J. B. P. A. Wijnberg, G. A. Stork, A. de Groot, M. A. de Waard, J. G. M. van Nistelrooy, 'The synthesis of mono- and dihydroxy aromadendrane sesquiterpenes, starting from natural (+)-aromadendrene-III', Tetrahedron 1992, 48, 2465-2476.

[65] J. M. Scher, J.-B. Speakman, J. Zapp, H. Becker, 'Bioactivity guided isolation of antifungal compounds from the liverwort Bazzania trilobata (L.) S. F. Gray.', Phytochemistry 2004, 65, 2583-2588.

[66] G. D. G. Stoner, H. Mukhtar, 'Polyphenols as cancer chemopreventive agents', J. Cell. Biochem. Suppl. 1995, 22, 169180.

[67] M. Alvarez-Guerra, P. Hannaert, H. Hider, C. Chiavaroli, R. P. Garay, 'Vascular permeabilization by intravenous arachidonate in the rat peritoneal cavity: Antagonism by antioxidants', Eur. J. Pharmacol. 2003, 466, 207-212.

[68] Q. Zheng, X. Sun, X. Bo, G. Li, S. Meng, C. Wang, 'Protective effects of luteolin-7-glucoside against liver injury caused by carbon tetrachloride in rats', Pharmazie 2004, 59, 286289.

[69] N. A. Parreira, L. C. Magalhaes, D. C. Morais, S. C. Caixeta, J.P. B. de Sousa, J. K. Bastos, W. R. Cunha, M. L. A. Silva, N. P. D. Nanayakkara, V. Rodrigues, A. A. da Silva Filho, 'Antiprotozoal, Schistosomicidal, and Antimicrobial Activities of the Essential Oil from the Leaves of Baccharis dracunculifolia', Chem. Biodiversity 2010, 7, 993-1001.

[70] I. M. Helander, H.-L. Alakomi, K. Latva-Kala, T. MattilaSandholm, I. Pol, E. J. Smid, L. G. M. Gorris, A. von Wright, 'Characterization of the Action of Selected Essential Oil Components on Gram-Negative Bacteria', J. Agric. Food Chem. 1998, 46, 3590-3595.
[71] R. Upton, A. Graff, G. Jolliffe, R. Länger, E. Williamson, 'American Herbal Pharmacopoeia: Botanical pharmacognosy - microscopy characterization of botanical medicines', CRC Press, Taylor and Francis Group, New York, 2011.

[72] J. M. Budel, J. P. de Paula, V. L. P. dos Santos, C. R. C. Franco, P. V. Farago, M. do R. Duarte, 'Pharmacobotanical study of Baccharis pentaptera', Braz. J. Pharmacogn. 2015, 25, 314319.

[73] T. Zuccolotto, Ph.D. Thesis, Federal University of Paraná at Curitiba, 2017.

[74] J. Bressan, Ph.D. Thesis, Federal University of Paraná at Curitiba, 2014.

[75] T. Zuccolotto, A. V. F. Lourenço, E. Bruginski, B. Alves, A. Veiga, F. S. Murakami, F. R. Campos, 'Antimicrobial Activity of the Crude Extracts and Fractions of Three Baccharis Species', Med. Chem. 2016, 6, 557-560.

[76] ANVISA, Agência Nacional de Vigilância Sanitária, 'Farmacopéia Brasileira - V', II, 5th edn., Brasilia, Fiocruz, 2010.

[77] A. C. De Oliveira, I. B. Valentim, M. O. F. Goulart, C. A. Silva, E. J. H. Bechara, M. T. S. Trevisan, 'Fontes Vegetais Naturais de Antioxidantes', Quim. Nova 2009, 32, 689-702.

[78] S. Takamatsu, T. W. Hodges, I. Rajbhandari, W. H. Gerwick, M. T. Hamann, D. G. Nagle, 'Marine natural products as novel antioxidant prototypes', J. Nat. Prod. 2003, 66, 605608.

[79] CLSI, 'Methods for Dilution Antimicrobial Susceptibility Tests for Bacteria That Grow Aerobically', CLSI document M07-A9, Clinical and Laboratory Standards Institute, Wayne, Pa, 2012.

[80] D. A. Johansen, 'Plant microtechnique', McGraw-Hill Book Company, London, 1940.

[81] G. P. Berlyn, J.P. Miksche, 'Botanical microtechnique and cytochemistry', lowa State University Press, Ames, lowa 1976.

[82] K. R. Roeser, 'Die Nadel der Schwarzkiefer-Massenprodukt und Kunstwerk der Natur.', Mikrokosmos 1972, 61, 33-36.

[83] J. E. Kraus, M. Arduin, 'Manual basico de metodos em morfologia vegetal', EDUR, Rio de Janeiro, 1997.

[84] F. R. Milanez, A. S. Foster, 'Practical plant anatomy', D. Van Nostrand, Inc., 1950.

Received October 19, 2018 Accepted February 4, 2019 